\title{
Heavy Metals in Zooplankton and Decapod Crustaceans from the Barents Sea*
}

\author{
G.-P. Zauke ${ }^{\star \star}$, I. Schmalenbach
}

Carl von Ossietzky Universität Oldenburg, ICBM

Postfach 2503, D-26111 Oldenburg, Germany

** Corresponding author; e-mail: gerd.p.zauke@uni-oldenburg.de

Homepage: http://www.icbm.de/ aqua/index.html

\begin{abstract}
Trace metals ( $\mathrm{Cd}, \mathrm{Cu}, \mathrm{Pb}$ and $\mathrm{Zn}$ ) were analysed in zooplankton samples and decapod crustaceans collected on cruises of "RV Walther Herwig III" to the Barents Sea (Summer 1991, 1994 and 2000). We found a substantial spatial heterogeneity in the decapod crustacean Pandalus borealis, with increasing $\mathrm{Cd}$ concentrations from the south (North Cape Bank; 0.7 $\mathrm{mg} \mathrm{kg}^{-1} \mathrm{DW}$ ) to the north (north of Svalbard; $4.7 \mathrm{mg} \mathrm{kg}^{-1}$ ), supporting the hypothesis that the frequently reported Cd-anomaly in polar crustaceans might be extended to the Barents Sea. Regarding various crustaceans and zooplankton collectives (2000) a distinct interspecific heterogeneity of metals was obvious, with lowest $\mathrm{Cd}$ concentrations in euphausiids and chaetognaths and highest ones in decapods and hyperiid amphipods; lowest Cu concentrations in chaetognaths and copepods and highest ones in euphausiids and decapods; and lowest $\mathrm{Zn}$ concentrations in euphausiids and decapods and highest ones in some copepods. For $\mathrm{Pb}$ many values were below or close to the limit of detection, suggesting that $\mathrm{Pb}$ concentrations about $0.4 \mathrm{mg} \mathrm{kg}^{-1}$ might serve as a regional background value. Results for $\mathrm{Cd}, \mathrm{Cu}$ and $\mathrm{Zn}$ in copepods of this study are largely within the reported range, but high $\mathrm{Cd}$ concentrations in copepods from summer in contrast to reported lower ones during winter/spring may be related either to changing accumulation strategies of the copepod species involved or to seasonally changing Cd absorption in copepods from food.
\end{abstract}

keywords: biomonitoring; trace metals; zooplankton; Cd-anomaly; spatial, intra- and interspecific heterogeneity

" pre-print: Science of the Total Environment (in press) 


\section{Introduction}

Contamination of the Arctic marine ecosystems with trace metals and other xenobiotics receives continued attention in the scientific literature and international environmental programmes (AMAP, 2004; OSPAR Commission, 2000; Riget et al., 2003). To assess the environmental quality regarding heavy metals in the oceans, the bioavailable fraction from food and water is of great importance. Both sources are integrated into accumulated concentrations in organisms. There is increasing evidence that trophic transfer may be even more important than dissolved uptake in various invertebrates (Wang, 2002). Further support of this view is provided by the fact that bioconcentration factors (BCFs) derived from field samples are often much higher than BCFs estimated from experiments regarding dissolved uptake (Kahle and Zauke, 2002b). Thus, the total bioavailable fraction is only accessible by determining the amount of metals incorporated in organisms (Zauke et al., 1996b). The accumulation patterns and subsequent accumulated concentrations in marine organisms are often varying specifically as can be explained and predicted by toxicokinetic modelling (Clason et al., 2004; Luoma and Rainbow, 2005). As a result, we frequently can find different species of zooplankton with greatly varying metal concentrations in the same body of ocean water (Kahle and Zauke, 2003; Petri and Zauke, 1993; Ritterhoff and Zauke, 1997d).

That zooplankton play an important role in the biogeochemical cycling of metals in marine systems in general is well known, especially regarding particle-reactive metals in the water column (Fisher et al., 1991; Lee and Fisher, 1994; Stewart et al., 2005). Thus, in several studies macro- and meso-zooplankton organisms have been specifically used as biomonitors for assessment of the bioavailability of elements in marine systems, covering a variety of spatial and temporal scales (e.g. Kahle and Zauke, 2003; Ritterhoff and Zauke, 1997d; Zauke et al., 1996a). Their potential suitability is largely due to their worldwide presence, their major role in the food webs and their high contribution to the total biomass in marine systems.

In order to differentiate human impact from natural variability, knowledge of background concentrations of metals and their fluctuations in biomonitor organisms is essential as well as a thorough understanding of accumulation and detoxification strategies (Luoma and Rainbow, 2005). Those depend on various aspects, including the biological species and element considered, the applied exposure regime, cation homeostasis mechanisms, life-history status, spatial and temporal scales and others.

Studies on zooplankton from polar regions have revealed particularly high Cd concentrations referred to as 'Cd-anomaly' (Bargagli et al., 1996; Petri and Zauke, 1993; Ritterhoff and Zauke, 1997d). It was hypothesized that they are related to effective but unselective uptake mechanisms which had evolved due to potential metabolic deficiencies in $\mathrm{Cu}$ in the Antarctic Ocean. These findings suggest that probably no global background values can be defined. Instead, regional background values should be established in order to follow possible future trends of metals in biomonitors.

An increasing body of information on metals in marine zooplankton has become available for specific regions such as the North Sea, the Greenland Sea and the Weddell Sea as intensively discussed in Zauke et al. (1996a), Ritterhoff and Zauke (1997d) and Kahle and Zauke 
(2003). For other areas such as the Barents Sea recent information on metals in offshore zooplankton and crustaceans is largely lacking, in contrast to other components of the marine food web like inshore benthic invertebrates (Zauke et al., 2003), fish (Zauke et al., 1999), sea birds (Savinov et al., 2003) and marine mammals (Booth and Zeller, 2005).The Barents Sea is an important area for commercial fisheries; with total annual yields reaching 3-4 million tons, it is comparable to Icelandic waters and the Norwegian Sea (Gjosaeter, 1995; Hansen et al., 1996). Because potential contamination of fish with heavy metals due to the marine food web might be crucial for the future exploitation of this resource, information on this issue is urgently needed.

The main goal of this paper is to provide further evidence for a Cd-anomaly in decapod crustaceans from Arctic waters. This hypothesis would be supported by high $\mathrm{Cd}$ concentrations compared to literature data from other regions and particularly by an increasing Cd gradient from the south to the north and will be tested using the decapod crustacean Pandalus borealis. Because the samples were taken in different years and the size of organisms varied largely, temporal and intraspecific heterogeneities of metals in $P$. borealis had to be evaluated in advance. Furthermore, other zooplankton taxa like copepods were investigated to test their suitability for establishing some regional background values to be used in future biomonitoring studies.

\section{Materials and methods}

\subsection{Sampling and sample preparation}

Samples were collected from FRV "Walther Herwig III" (cruise 217, May/June, 2000) in four regions of the Norwegian Sea and the Barents Sea at 25 stations (Fig. 1): area 1, North Cape Bank ( $71^{\circ} 30.5$ 'N -71 ${ }^{\circ} 37.5$ 'N and $24^{\circ} 50.0^{\prime} \mathrm{E}-25^{\circ} 13.8$ 'E, 250-300 m depth); area 2,

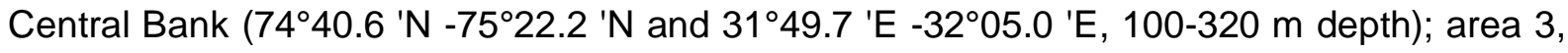
Spitsbergen Bellsund Bank, Hornsund Bank and South Cape Bank $\left(76^{\circ} 30.3\right.$ 'N $-77^{\circ} 26.5$ 'N and $12^{\circ} 29.9^{\prime} \mathrm{E}-14^{\circ} 14.5$ 'E; 220-300m depth) and area 4, Bear Island $\left(74^{\circ} 11.5^{\prime} \mathrm{N}-74^{\circ} 35.5\right.$ 'N and $16^{\circ} 09.5$ 'E-17 26.5 'E, 200-480 m depth). Additional data were evaluated originating from two other cruises of Walther Herwig II and III in the same region; namely cruise 116, July, 1991 at 2 stations (area 5, north of Svalbard: $81^{\circ} 18.0^{\prime} \mathrm{N}$ and 1840.0 'E, 400-500 m depth) and cruise 150, August, 1994 at 3 stations (area 3, Spitsbergen Bellsund Bank: $77^{\circ} 14.4$ ' $\mathrm{N}$ and $12^{\circ} 49.2$ 'E, 204-211 m depth and area 2, Central Bank: $75^{\circ} 13.6$ ' $\mathrm{N}$ and $32^{\circ} 26.3$ 'E, 274 m depth).

Zooplankton samples were taken with a vertically towed plankton net (the so-called 'Helgoländer Planktonnetz', a net originally used to catch ichthyoplankton, with a mesh size of $500 \mu \mathrm{m}$ and a diameter of $1 \mathrm{~m}$ ), which was hauled at $0.7 \mathrm{~m} \mathrm{sec}^{-1}$ from depths of $200-460 \mathrm{~m}$, depending on the station. Decapod samples originate from catches with the standard fishing trawl GOV (Chalut à Grande Ouverture Verticale) from depths of 170-330 m, with trawling time of 30 min at a trawling speed of 4 knots.

On board ship zooplankton from the 'Helgoländer Planktonnetz' was transferred to polyethylene buckets and kept alive in sea water collected from depths $>100 \mathrm{~m}$ for at least $1-3 \mathrm{~h}$ to allow for defecation. We assume complete defecation within this period as gut transit times in 
copepods are less than $0.5 \mathrm{~h}$ at $18^{\circ} \mathrm{C}$ (Reinfelder and Fisher, 1991). The animals were then sorted, still alive, under a binocular microscope to the species level, yielding the following samples: Calanus finmarchicus (Gunnerus, 1765); Calanus hyperboreus Krøyer, 1838; Euchaeta norvegica (Boeck, 1872) and Metridia longa (Lubbock, 1854) (Copepoda); Themisto abyssorum (Boeck, 1870) and Themisto libellula (Mandt, 1867) (Amphipoda); Meganyctiphanes norvegica (M. Sars, 1875) (Euphausiacea) and Eukronia hamata (Möbius, 1875) (Chaetognatha). The decapods from the GOV were treated likewise, yielding the following samples: Sabinea sarsi Smith, 1879 and Pandalus borealis Krøyer, 1844. The size of P. borealis was classified as follows (rostrum to telson): small $(5.0-7.5 \mathrm{~cm})$, medium $(7.5-10.5$ $\mathrm{cm})$, large $(10.5-12.0 \mathrm{~cm})$.

Subsequently, the zooplankton samples were briefly, the decapods thoroughly rinsed with double-distilled water, dried on good-quality filter paper and stored at $-30^{\circ} \mathrm{C}$ in Eppendorf caps ( $2 \mathrm{ml}$, polypropylene), Petri dishes or good-quality polyethylene bags, depending on their size and number (normally consisting of 20 specimens of $P$. borealis and 7 specimens of $S$. sarsi). To assure the quality of the sampling procedure, we followed the guidelines set up in Zauke et al. (1996a) and Zauke and Petri (1993). The risk of contamination was largely reduced by, firstly, keeping the animals in sea water or on high-quality filter paper whenever possible. Secondly, the absence of contaminating particles such as paint particles was guaranteed by close visual examination of each specimen collected.

\subsection{Analytical procedures}

Upon arrival in the laboratory in Oldenburg, the frozen crustacean samples were subjected to freeze-drying for $72 \mathrm{~h}$ to remove remaining water (LYOVAG GT2, Leybold Heraeus). Then the samples were homogenised using a small boron carbide mortar and pestle, to avoid losses of biomass, or a ball mill made of agate. Aliquots of about $10 \mathrm{mg}$ dried material were digested for $3 \mathrm{~h}$ at $80^{\circ} \mathrm{C}$ with $100 \mu \mathrm{HNO}_{3}$ (65\%, suprapure, Merck) in tightly closed 2-ml Eppendorf reaction tubes (Clason and Zauke, 2000). The digests were made up to $2 \mathrm{ml}$ volume with double distilled water.

Metal determinations in biological samples were performed using a Varian SpectrAA 880 Zeeman instrument and a GTA 110 graphite tube atomiser with Zeeman background correction according to Clason and Zauke (2000) and Kahle et al. (2003). Ashing and atomisation temperatures were 600 and $1800{ }^{\circ} \mathrm{C}$ for $\mathrm{Cd}, 1000$ and $2200^{\circ} \mathrm{C}$ for $\mathrm{Pb}, 800$ and $2300^{\circ} \mathrm{C}$ for $\mathrm{Cu}$. For $\mathrm{Cd}$ and $\mathrm{Pb}$, palladium and magnesium nitrate modifiers were applied. $\mathrm{Zn}$ was assayed using an air-acetylene flame (SpectrAA-30, deuterium background correction) and a manual micro-injection method (100 $\mu$ sample volume). All metal concentrations in biological tissues are reported in $\mathrm{mg} \mathrm{kg}^{-1}\left(\mu \mathrm{g} \mathrm{g}^{-1}\right)$ dry weight (DW). We obtained the following fresh weight / dry weight ratios: 4.1 for $P$. borealis and $S$. sarsi, 4.7 for $M$. norvegica, 5.1 for $E$. norvegica and $T$. abyssorum, 5.8 for $M$. longa, 6.2 for $C$. finmarchicus, 8.4 for $C$. hyperboreus, and 9.9 for E. hamata.

Quality assurance was performed in line with German GLP regulations (Anonymous, 1999), using the following documented criteria: stability of instrumental recalibration, precision of parallel injections (normally showing a coefficient of variation of 1-5\%) and analytical blanks 
(also reflecting the digestion procedure). The precision and validity were evaluated using three certified reference materials which were randomly allocated within the determinations (see Table 1). Limits of detection were calculated according to Büttner et al. (1980). The analysed values obtained for reference materials are in most cases in excellent agreement with the certified values, and the limits of detection proved to be adequate for the range of metal concentrations found in this study for marine zooplankton and crustaceans. Only for $\mathrm{Pb}$ we find many values below or close to the limit of detection. Thus, $\mathrm{Pb}$ was not considered in the statistical data evaluation.

\subsection{Statistical procedures}

The hypothesis of normal distribution was tested using the Lilliefors Test (referred to as LIP; $\alpha=0.01$ ) provided in SYSTAT for Windows (Version 8, Wilkinson, 1998). We selected the $99 \%$ significance level because the following parametric tests employed are regarded to be robust against deviations from the normal distribution. Since they have more power compared to the nonparametric procedures, it is reasonable not to reject these tests too early. The same program was also used to compute means and $95 \%$ confidence intervals of metal concentrations in independent subsamples. The experimental units of this study are given for $P$. borealis by the factors body size, time of sampling and the different study areas within the Barents Sea and adjacent waters as shown in Fig. 1 and for the zooplankton in general by the factor species affiliation. A multiway ANOVA was not applicable due to the resulting low degrees of freedom and the occurrence of empty cells in the different factor levels. Thus, these factors had to be analysed and discussed stepwise.

Further statistical evaluation was performed with BMDP Dynamics (Release 7.0, Dixon, 1992). Global null hypotheses (e.g. equality of means between the species investigated, viz. interspecific heterogeneities) were tested either by classical ANOVA (assuming equality of variances; referred to as $\mathrm{F}$ ), by non-classical Welch Test (not assuming equality of variances; WS) or by non-parametric Kruskal-Wallis Test $(\mathrm{H})$. In case of two sample comparisons these tests yield the same results as the pooled or separate variance t-Test or the Mann-Whitney Test. The adequate procedure was selected after testing for normality by Lilliefors Test (SYSTAT) and equality of variances by Levene Test (BMDP, LS). Null hypotheses were rejected at 95\% significance level $(P<0.05)$.

Heterogeneity was analysed in more detail using the non-parametric multiple comparison $Z$ statistic or the Student-Newman-Keuls Multiple Range Test (NK) $(\alpha=0.05)$. The robust NK procedure involves an adjusted significance level for each group of ordered means (Dixon, 1992; p. 585). We did not consider applying a log transformation to the data and employing a classical ANOVA, because in this case the interpretation of the statistical results would be restricted to the transformed data and not to the original ones which are of interest. This disadvantage is avoided by the well established procedures mentioned above. 


\section{Results}

\subsection{Size dependent metal concentrations in Pandalus borealis}

Statistical results for size-dependent heterogeneities of metals in $P$. borealis are compiled in Table 2. Parametric tests are used because Lilliefors probabilities $>0.01$ indicate that the sample data are distributed normally. The results vary depending on the area and element considered. Regarding area 2 and 3 we find statistically significant differences for $\mathrm{Cd}$ and $\mathrm{Cu}$. Larger specimens (see note under Table 2 for definition of sizes) tend to have higher metal concentrations than smaller ones $\left(2.3-2.5\right.$ vs. $1.3-1.4 \mathrm{mg} \mathrm{Cd} \mathrm{kg}^{-1}$ and $50-112$ vs. $40-50$ $\mathrm{mg} \mathrm{Cu} \mathrm{kg}{ }^{-1}$, respectively). For $\mathrm{Zn}$ no significant differences could be detected. Regarding area 5 significant differences are identified for $\mathrm{Cu}$ and $\mathrm{Zn}$ showing the same size dependency as mentioned above (20 vs. $56 \mathrm{mg} \mathrm{Cu} \mathrm{kg}^{-1}$ and 48 vs. $58 \mathrm{mg} \mathrm{Zn} \mathrm{kg}^{-1}$, respectively). No significant differences are obvious for $\mathrm{Cd}$. The implication of these findings will be discussed more detailed below.

\subsection{Temporal and spatial heterogeneities of metals in Pandalus borealis}

Temporal heterogeneities of metals in $P$. borealis have to be analysed to decide whether the data can be pooled for the subsequent evaluation of the spatial heterogeneities which is one important goal of this study. For this purpose results are available for areas 2 and 3, unfortunately indicating a temporal heterogeneity for all elements analysed, with the sole exception of $\mathrm{Cd}$ regarding area 3, 1994 vs. $2000(\mathrm{H}=3.2 ; \mathrm{P}=0.072 ; \mathrm{df}=1,78)$. Therefore, the data cannot be pooled and are compiled (grouped by area and year) in Table 3 in an increasing sequence of metal concentrations, showing means and 95\%-confidence intervals and results of the Lilliefors Test. Since for some groups the null hypothesis (normality of the data) has to be rejected (LIP values $<0.01$ ), comparisons involving those groups is done using the $Z$ statistic, otherwise using the NK procedure.

Despite an increased variability probably introduced by the factor time, a clear increasing spatial trend of $\mathrm{Cd}$ in $P$. borealis from south (area 1) to north (area 5 ) is indicated by the result of the $Z$ statistic, while data from areas 2 and 3 are overlapping (Table 3 ). Such a trend is missing for $\mathrm{Cu}$ and $\mathrm{Zn}$, despite some spatial heterogeneities occurring between areas 2 and 3 in 1994 (Cu: $H=14.3 ; P=0.000 ; d f=1,84 ; Z n: F=65.2 ; P=0.000 ; d f=1$, 83; notation see Table 2) and between areas 1, 2 and 3 in 2000 ( $\mathrm{Cu}: \mathrm{H}=30.5 ; \mathrm{P}=0.000 ; \mathrm{df}=2,43$; $\mathrm{Zn}: \mathrm{WS}=9.2 ; \mathrm{P}=0.001 ; \mathrm{df}=2,21$.

\subsection{Interspecific heterogeneities of metals in decapod crustaceans and zooplankton}

Results on metal concentrations in various crustaceans and zooplankton collectives (2000) are compiled in Table 4, showing means and 95\%-confidence intervals and results of the Lilliefors Test. Since the null hypothesis (normality of the data) has to be rejected only in a few cases (LIP values < 0.01 ) robust parametric tests are employed. Tests of global null hypotheses (equality of means) indicate significant interspecific heterogeneities for all elements considered $(\mathrm{Cd}$ : $\mathrm{WS}=78.8 ; \mathrm{P}=0.000 ; \mathrm{df}=7,31 ; \mathrm{Cu}$ : $\mathrm{WS}=49.7 ; \mathrm{P}=0.000 ; \mathrm{df}=8,24 ; \mathrm{Zn}$ : $W S=63.3 ; P=0.000 ; d f=8,25)$. A more detailed analysis of heterogeneities is given by re- 
sults of the robust NK procedure (Table 4). For Cd we find lowest concentrations in euphausiids and chaetognaths and highest ones in hyperiid amphipods; for Cu lowest ones in chaetognaths and copepods and highest ones in euphausiids and decapods; and for Zn lowest ones in euphausiids and decapods and highest ones in some copepods. For $\mathrm{Pb}$ a statistical comparison is not applicable because many values are below or close to the limit of detection $\left(0.4 \mathrm{mg} \mathrm{kg}^{-1}\right)$; slightly increased values are only obtained for Themisto abyssorum (mean $\pm 95 \%$-confidence interval: $0.8 \pm 0.5 \mathrm{mg} \mathrm{kg}^{-1}$ d.w., $\left.\mathrm{N}=6\right)$, Pandalus borealis $(1.0 \pm 0.2 \mathrm{mg} \mathrm{kg}$

$\left.{ }^{1}, \mathrm{~N}=47\right)$ and Sabinea sarsi (1.5 $\left.\pm 0.3 \mathrm{mg} \mathrm{kg}^{-1}, \mathrm{~N}=6\right)$.

\section{Discussion}

\subsection{Heterogeneities of metals in Pandalus borealis}

The size-dependent increase of $\mathrm{Cd}$ and $\mathrm{Cu}$ in $P$. borealis from smaller to larger specimens is in good agreement with results reported by Ritterhoff and Zauke (1997c) for the amphipod Themisto libellula from the Greenland Sea. Pronounced intraspecific heterogeneities were also reported for some Antarctic crustaceans like the isopod Ceratoserolis trilobitoides, the decapod Notocrangon antarcticus and the amphipod Eusirus propeperdentatus (Zauke and Petri, 1993), showing an increase of whole-body $\mathrm{Cu}$ concentrations with increasing body length for the decapod and the amphipod. The detected heterogeneity in the isopod was related to the sex status. In both studies such increase was absent for $\mathrm{Zn}$, in contrast to the present paper. Contradictory results were, however, also obtained for estuarine gammarids in toxicokinetic studies, where kinetic model parameters $\left(k_{1}\right.$ : rate constants for uptake and $\mathrm{BCF}$ : bioconcentration factors) for $\mathrm{Cd}, \mathrm{Cu}, \mathrm{Pb}$ and $\mathrm{Zn}$ decreased with increasing body length of the amphipod Gammarus zaddachi (Wang and Zauke, 2004). Not only sex and body length may be important in determining accumulated metal concentrations in amphipods, but also the fecundity status of the females, as has been shown for gammarids from a Weser estuary modelling study (Bäumer et al., 1991).

Not taking into account such effects may lead to a bias in the study, if, for example, spatially different samples are composed of differently sized organisms. This is not the case in our study, because samples of $P$. borealis from all areas and times of sampling largely consisted of all size groups. However, since the organisms were analysed individually, we have to encounter an increased variability in all groups, eventually preventing detection of more significant differences in the subsequent statistical analyses.

Distinct spatial heterogeneities of metals in organisms as shown in this study for $P$. borealis (Table 3) may be caused by different metal speciation and hence bioavailabilities between water masses due to variations in the salinity (psu). Information on water masses in our investigation areas (AMAP, 1998; OSPAR Commission, 2000) suggest, however, that the reported salinity differences are too low (North Cape Bank: 34.7 - 34.9 psu; Central Bank: 34.8 - 35.0 psu; Spitsbergen Bellsund Bank: 34.1 - 34.8 psu) to lead to such an effect. Furthermore, there is no evidence of distinctly different metal concentrations in seawater in the Arctic, supporting the hypothesis that the observed spatial differences especially of $\mathrm{Cd}$ in $P$. borealis might be related to different accumulation strategies in organisms from our investigation areas (see next sections for further discussion). 


\subsection{Interspecific heterogeneities of metals in decapod crustaceans and zooplankton}

From Table 4 a distinct interspecific heterogeneity of metal concentrations is obvious. Regarding results of the NK procedure it must be taken into account that this test represents a multiple comparison option. If the data vary to a great extent, then possible differences in the lower range might be hidden by higher values, as has been found for $\mathrm{Cu}$. Thus, when only copepods are taken into account then $C$. hyperboreus is significantly different from $C$. finmarchicus and $M$. longa, and these in turn are significantly different from $E$. norvegica. A similar phenomenon was reported by Ritterhoff and Zauke (1997d).

Heavy-metal concentrations in various marine pelagic crustaceans and in zooplankton reported in the literature are compiled in Tables 5 and 6. Generally, $\mathrm{Pb}$ concentrations are low $\left(<0.3-2.7 \mathrm{mg} \mathrm{kg}^{-1}\right)$ in agreement with results of the present study, probably indicating some regional background values in the organisms under study. Regarding $\mathrm{Cd}, \mathrm{Cu}$ and $\mathrm{Zn}$ the reported patterns are also in good agreement with the interspecific heterogeneities obtained in this study, viz. low Cd concentrations in euphausiids (about $0.2 \mathrm{mg} \mathrm{kg}^{-1}$ ) and high ones in decapods and amphipods (10-50 mg kg-1); low Cu concentrations in copepods (4-10 mg kg-1) and high ones in euphausiids and decapods (30-70 $\mathrm{mg} \mathrm{kg}^{-1}$ ); and finally intermediate $\mathrm{Zn}$ concentrations in almost all taxa (30-90 mg kg-1) with the sole exception of copepods, where especially in samples of Euchaeta and Metridia high concentrations were found (160-500 mg $\left.\mathrm{kg}^{-1}\right)$.

\subsection{Hypothesis of a Cd-anomaly and Cu-deficiency in decapods inferred from literature data}

The phenomenon of a polar Cd-anomaly which has been intensively discussed in the literature (e.g. Bargagli et al., 1996; Bustamante et al., 1998; Petri and Zauke, 1993; Ritterhoff and Zauke, 1997d) refers to the fact that we find species with low and high Cd concentrations in the same water mass and/or that polar Cd concentrations are higher than values from other regions. Our results compiled in Tables 3 and 4 support this idea, especially regarding the decapod crustacean Sabinea sarsi, the copepods Calanus hyperboreus and $C$. finmarchicus and the amphipod Themisto abyssorum. This view is further supported by the pronounced increase of $\mathrm{Cd}$ in Pandalus borealis in this study (Table 3), from the North Cape Bank $\left(0.7 \mathrm{mg} \mathrm{kg}^{-1} ; 71^{\circ} 30.5^{\mathrm{N}} \mathrm{N}\right)$ to waters north of Svalbard $\left(4.7 \mathrm{mg} \mathrm{kg}^{-1} ; 81^{\circ} 18.0\right.$ ' $\left.\mathrm{N}\right)$.

It is striking that a similar $\mathrm{Cd}$ gradient regarding whole-body concentrations (geometric means) was reported for $P$. borealis from western and eastern Greenland waters for the years 1985-1987 (cited from Dietz et al., 1998, p. 485): Nanortalik (1.8 mg kg-1;60.2 $\mathrm{N}$ ), Nuuk $\left(2.0 \mathrm{mg} \mathrm{kg}^{-1} ; 64.2^{\circ} \mathrm{N}\right)$, Maniitsoq $\left(1.3 \mathrm{mg} \mathrm{kg}^{-1} ; 65.4^{\circ} \mathrm{N}\right)$, Ammassalik $\left(2.4 \mathrm{mg} \mathrm{kg}^{-1}\right.$; $\left.65.6^{\circ} \mathrm{N}\right)$, Sisimiut $\left(1.8 \mathrm{mg} \mathrm{kg}^{-1} ; 66.9^{\circ} \mathrm{N}\right)$, Kangatsiaq $\left(2.6 \mathrm{mg} \mathrm{kg}^{-1} ; 68.3^{\circ} \mathrm{N}\right)$, Qeqertarssuaq $\left(4.1-5.1 \mathrm{mg} \mathrm{kg}^{-1} ; 69.8^{\circ} \mathrm{N}\right)$, Uummannaq $\left(2.4-4.3 \mathrm{mg} \mathrm{kg}^{-1} ; 71.5^{\circ} \mathrm{N}\right)$ and Upernavik $(5.2 \mathrm{mg}$ $\mathrm{kg}^{-1} ; 74^{\circ} \mathrm{N}$ ). As emphasized in a recent review (Riget et al., 2004 and the literature cited therein), substantial differences were also reported on more local scales, with two to five times greater $\mathrm{Cd}$ concentrations in Mytlilus edulis and $P$. borealis from the open sea compared to the inner fjord systems of Greenland.

Reported Cd concentrations in polar decapod crustaceans and hyperiid amphipods are also high (Table 5), but there are some indications that this phenomenon may be extended to 
other marine areas like the Iberian Deep Sea Plain (Prowe et al., in press). Most of the regions mentioned so far are considered to be rather isolated, so that high $\mathrm{Cd}$ concentrations in polar and deep sea crustaceans cannot be related to anthropogenic influences. Regarding the Antarctic Ocean they are thought to indicate a Cu deficiency (Petri and Zauke, 1993; Zauke and Petri, 1993). It has been hypothesised that a potential copper deficiency might be related to an increased uptake of $\mathrm{Cd}$ due to insufficient selectivity of the uptake process for the essential element $\mathrm{Cu}$, e.g. when metal-binding proteins are involved (Ritterhoff and Zauke, 1998). Theoretical considerations have suggested metabolic requirements for decapods from temperate waters such that about 7-15 $\mathrm{mg} \mathrm{kg}^{-1} \mathrm{DW}$ of total body Cu would be sufficient for enzymatic requirements and about $25 \mathrm{mg} \mathrm{kg}^{-1}$ would satisfy the haemocyanin component demand, giving a total of about 30 - $40 \mathrm{mg} \mathrm{Cu} \mathrm{kg}^{-1}$ (Rainbow, 1993; Rainbow, 1996).Thus, some of the $P$. borealis analysed in this study (Table 3) and some decapod crustaceans from other polar regions and from the Iberian Deep Sea Plain (Table 5) might be suffering $\mathrm{Cu}$ deficiencies in a sense that the total metabolic requirements have probably not been met.

Zn concentrations in decapods of this study (Table 4) are largely within the range reported for comparable organisms in the literature (Table 5). These results support the conclusions of Rainbow and White (1989), that decapods are able to regulate their $\mathrm{Zn}$ body concentrations, probably leading to whole-body concentrations that are comparable worldwide. Estimated enzymatic requirements for $\mathrm{Zn}$ in decapods are about $20 \mathrm{mg} \mathrm{kg}^{-1}$ (Rainbow, 1993; Rainbow, 1996), which are met for P. borealis and S. sarsi in this study.

\subsection{Further assessment of detected metal concentrations in zooplankton}

Regarding copepods, high Cd concentrations found in this study (Table 4) are generally in agreement with data from other polar regions (Table 6, Weddell Sea, Fram Strait, Greenland Sea). Noteworthy are, however, deviations of Cd in copepods reported by Pohl (1992), with high Cd concentrations obtained from organisms collected from surface layers during the Arctic summer (July 1990), in agreement with our data, and by Ritterhoff and Zauke (1997d), who found low $\mathrm{Cd}$ concentrations in organisms collected from water depths down to $1500 \mathrm{~m}$ by the end of the Arctic winter. Possible explanations for these differences detected in field samples from the two studies may be related either to changing accumulation strategies of the copepods involved or to seasonally changing $\mathrm{Cd}$ absorption in copepods from food during summer when they intensively feed on phytoplankton, while the food uptake path is irrelevant in winter (see Ritterhoff and Zauke, 1997d for further discussion). Furthermore, local upwelling might be related to increased $\mathrm{Cd}$ bioavailabilities in seawater and hence increased uptake into copepods as hypothesised for the northern North Sea (Zauke et al., 1996a). Thus, we cannot regard our data for copepods as an indication of a Cd-anomaly without further evaluation. This might involve toxicokinetic experiments also in the summer time, since Ritterhoff and Zauke (1997a, b) have not found any relevant uptake of water-borne cadmium in bioaccumulation experiments performed during the winter cruise.

Even if $\mathrm{Cu}$ requirements for copepods are considered to be similar to those of decapods (which has to be proven in future studies) they must be lower, because copepods, but also 
some hyperiid amphipods like Themisto, lack haemocyanin (Gruner et al., 1993). Thus, most of the data compiled in Tables 4 and 6 probably suggest some Cu deficiency for calanoid copepods.

\section{Conclusions}

Our study provides further evidence for the frequently reported Cd-anomaly in polar crustaceans, especially regarding a pronounced increase of $\mathrm{Cd}$ in Pandalus borealis from the North Cape Bank to waters north of Svalbard, in good agreement with a similar trend reported for Greenland waters. We suggest that this phenomenon might be related to a corresponding deficiency in essential trace elements like $\mathrm{Cu}$. This could be the consequence of efficient uptake mechanisms for $\mathrm{Zn}$ or $\mathrm{Cu}$ that cannot discriminate between those elements and $\mathrm{Cd}$. To test this hypothesis, further experimental studies are required, investigating in more detail, e.g., the role of metal-binding proteins in this process. Our data on zooplankton and crustacean samples suggest that $\mathrm{Pb}$ concentrations below $1 \mathrm{mg} \mathrm{kg}^{-1}$ might serve as a regional background value for comparison in biomonitoring studies. Size dependent, temporal, spatial as well as interspecific heterogeneities of metals detected in this study indicate that the organisms investigated might serve as suitable biomonitors. This has to be further evaluated by toxicokinetic bioaccumulation studies on board ship as previously reported for other polar waters (Kahle and Zauke, 2002a, b; Ritterhoff and Zauke, 1997a, b).

\section{Acknowledgements}

We thank the captain and crew of the RV Walther Herwig III as well as the Bundesforschungsanstalt für Fischerei, Hamburg for their kind cooperation during the cruise to the Barents Sea and for providing Fig. 1. The help of Heidi Scharvogel, Astrid Ahke and Arne Dübecke in sampling and sorting the organisms on board ship and of Dr. D.-L. Wübben in analysing the 1991 and 1994 data is gratefully acknowledged. Part of the experimental work was done by I.S. within her diploma thesis in marine environmental science at the $\mathrm{CvO}$ University of Oldenburg.

\section{References}

AMAP. AMAP assessment report: Arctic pollution issues. Arctic Monitoring and Assessment Programme (AMAP), Oslo, Norway, 1998, 859 pp.

AMAP. AMAP Assessment 2002: Heavy Metals in the Arctic -Pre-print files. Arctic Monitoring and Assessment Programme; http://www.amap.no/, Oslo, Norway, 2004.

Anonymous. Chemikaliengesetz: Gesetz zum Schutz vor gefährlichen Stoffen. Anhang 1 (zu $\S 19 a$ Abs. 1) - Grundsätze der guten Laborpraxis (GLP). In: Steinberg C, Bernhardt H, Calmano W, Klapper H, Wilken R-D, editors. Handbuch angewandte Limnologie, Chapter IX-5, 7 ErgLfg 4/99. ecomed, Landsberg am Lech, 1999.

Bargagli R, Nelli L, Ancora S, Focardi S. Elevated cadmium accumulation in marine organisms from Terra Nova Bay (Antarctica). Polar Biol 1996; 16: 513-520.

Bäumer H-P, van der Linde A, Zauke G-P. Structural equation models, applications in biological monitoring. Biometrie und Informatik in Medizin und Biologie 1991; 22: 156-178. 
Booth S, Zeller D. Mercury, food webs, and marine mammals: Implications of diet and climate change for human health. Environ Health Perspect 2005; 113: 521-526.

Bustamante P, Cherel Y, Caurant F, Miramand P. Cadmium, copper and zinc in octopuses from Kerguelen Islands, Southern Indian Ocean. Polar Biol 1998; 19: 264-271.

Büttner JR, Borth R, Boutwell HJ, Broughton PMG, Bowyer RC. Approved recommendation (1978) on quality control in clinical chemistry. J Clin Chem Clin Biochem 1980; 18: 78-88.

Clason B, Langston WJ, Zauke G-P. Bioaccumulation of trace metals in the amphipod Chaetogammarus marinus (Leach, 1815) from the Avon and Tamar estuaries (UK): comparison of two-compartment and hyperbolic toxicokinetic models. Mar Environ Res 2004; 57 : 171-195.

Clason B, Zauke G-P. Bioaccumulation of trace metals in marine and estuarine amphipods: evaluation and verification of toxicokinetic models. Can J Fish Aquat Sci 2000; 57: 14101422.

Dietz R, Pacyna JM, Thomas DJ, Asmund G, Gordeev V, Johansen P, Kimstach V, Lockhart L, Pfirman SL, Riget FF, Shaw G, Wagemann R, White M. Chapter 7: Heavy metals. In: Arctic Monitoring and Assessment Programme, editors. AMAP assessment report: Arctic pollution issues. Oslo, Norway, 1998; pp. 373-524.

Dixon WJ, eds. BMDP statistical software manual (version 7.0), Volume 1. University Press of California, Berkeley, CA, USA, 1992, pp. 678.

Fisher NS, Nolan CV, Fowler SW. Assimilation of metals in marine copepods and its biogeochemical implications. Mar Ecol Prog Ser 1991; 71: 37-43.

Fossi MC, Borsani JF, Di Mento R, Marsili L, Casini S, Neri G, Mori G, Ancora S, Leonzio C, Minutoli R, de Sciara GN. Multi-trial biomarker approach in Meganyctiphanes norvegica: a potential early indicator of health status of the Mediterranean "whale sanctuary". Mar Environ Res 2002; 54: 761-767.

Gjosaeter H. Pelagic fish and the ecological impact of the modern fishing industry in the Barents Sea. Arctic 1995; 48: 267-278.

Gruner H-E, Moritz M, Dunger W. Lehrbuch der speziellen Zoologie (begr. von A. Kaestner), Wirbellose Tiere, 4. Teil: Arthropoda (ohne Insecta). Gustav Fischer, Stuttgart, 1993, $1280 \mathrm{pp}$.

Hansen JR, Hansson R, Norris S. The state of the European Arctic environment. European Environmental Agency and Norwegian Polar Institute, Copenhagen, 1996, 136 pp.

Kahle J, Clason B, Zauke G-P. Sequential determination of $\mathrm{Cd}, \mathrm{Cu}, \mathrm{Pb}$, Co and $\mathrm{Ni}$ in marine invertebrates by graphite furnace atomic absorption spectroscopy and Zeeman background correction. Varian AA at Work No 129 2003; 1-15.

Kahle J, Zauke G-P. Bioaccumulation of trace metals in the calanoid copepod Metridia gerlachei from the Weddell Sea (Antarctica). Sci Total Environ 2002a; 295: 1-16.

Kahle J, Zauke G-P. Bioaccumulation of trace metals in the copepod Calanoides acutus from the Weddell Sea (Antarctica): comparison of two-compartment and hyperbolic toxicokinetic models. Aquat Toxicol 2002b; 59: 115-135.

Kahle J, Zauke G-P. Trace metals in Antarctic copepods from the Weddell Sea (Antarctica). Chemosphere 2003; 51: 409-417.

Leatherland TM, Burton JD, Culkin F, McCartney MJ, Morris RJ. Concentrations of some trace metals in pelagic organisms and of mercury in Northeast Atlantic Ocean water. Deep - Sea Res 1973; 20: 679-685.

Lee B-G, Fisher NS. Effects of sinking and zooplankton grazing on the release of elements from planktonic debris. Mar Ecol Prog Ser 1994; 110: 271-281. 
Luoma SN, Rainbow PS. Why is metal bioaccumulation so variable? Biodynamics as a unifying concept. Environ Sci \& Technol 2005; 39: 1921-1931.

OSPAR Commission. Quality Status Report 2000, Region I - Arctic Waters. OSPAR Commission, London, 2000.

Petri G, Zauke G-P. Trace-Metals in Crustaceans in the Antarctic Ocean. Ambio 1993; 22: 529-536.

Pohl C. Wechselbeziehungen zwischen Spurenmetallkonzentrationen ( $\mathrm{Cd}, \mathrm{Cu}, \mathrm{Pb}, \mathrm{Zn})$ im Meerwasser und in Zooplanktonorganismen (Copepoda) der Arktis und des Atlantiks. Ber Polarforsch 1992; 101: 1-198.

Prowe F, Kirf M, Zauke G-P. Heavy metals in crustaceans from the Iberian Deep Sea Plain. Sci Mar in press.

Rainbow PS. The significance of trace metal concentration in marine invertebrates. In: Dallinger R, Rainbow PS, editors. Ecotoxicology of metals in invertebrates. Lewis Publishers, Boca Raton, USA, 1993; pp. 4-23.

Rainbow PS. Heavy metals in aquatic invertebrates. In: Beyer WN, Heinz GA, RedmonNorwood AW, editors. Environmental contaminants in wild life: Interpreting tissue concentrations. Lewis Publishers, Boca Raton, USA, 1996; pp. 405-425.

Rainbow PS, White SL. Comparative strategies of heavy metal accumulation by crustaceans: Zinc, copper and cadmium in a decapod, an amphipod and a barnacle. Hydrobiologia 1989; 174: 245-262.

Reinfelder JR, Fisher NS. The assimilation of elements ingested by marine copepods. Science 1991; 251: 794-796.

Ridout PS, Rainbow PS, Roe HSJ, Jones HR. Concentrations of V, Cr, Mn, Fe, Ni, Co, Cu, $\mathrm{Zn}$, As and $\mathrm{Cd}$ in mesopelagic curstaceans from the North East Atlantic Ocean. Mar Biol 1989; 100: 465-471.

Ridout PS, Willcocks AD, Morris RJ, White SL, Rainbow PS. Concentrations of Mn, Fe, Cu, $\mathrm{Zn}$ and $\mathrm{Cd}$ in the mesopelagic decapod Systellaspis debilis from the East Atlantic Ocean. Mar Biol 1985; 87: 285-288.

Riget F, Dietz R, Vorkamp K, Johansen P, Muir D. Levels and spatial and temporal trends of contaminants in Greenland biota: an updated review. Sci Total Environ 2004; 331: 29-52.

Riget F, Johansen P, Glasius M, Vorkamp K, Dahlgaard H, Muir D, Asmund G, Born EW. Marine Environment. Chapter 4. In: Riget $F$, Christensen J, Johansen $P$, editors. AMAP Greenland and the Faroe Island 1997-2001 Vol 2: The environment of Greenland. Ministry of the Environment, Danish EPA, Copenhagen, 2003; pp. 67-114.

Ritterhoff J, Zauke G-P. Bioaccumulation of trace metals in Greenland Sea copepod and amphipod collectives on board ship: verification of toxicokinetic model parameters. Aquat Toxicol 1997a; 40: 63-78.

Ritterhoff J, Zauke G-P. Evaluation of trace metal toxicokinetics in Greenland Sea copepod and amphipod collectives from semi-static experiments on board ship. Polar Biol 1997b; 17: $242-250$.

Ritterhoff J, Zauke G-P. Influence of body length, life-history status and sex on trace metal concentrations in selected zooplankton collectives from the Greenland Sea. Mar Pollut Bull 1997c; 34: 614-621.

Ritterhoff J, Zauke G-P. Trace metals in field samples of zooplankton from the Fram Strait and the Greenland Sea. Sci Total Environ 1997d; 199: 255-270. 
Ritterhoff J, Zauke G-P. Potential role of metal-binding proteins in cadmium detoxification in Themisto libellula (Mandt) and Themisto abyssorum Boeck from the Greenland sea. Mar Environ Res 1998; 45: 179-191.

Savinov VM, Gabrielsen GW, Savinova TN. Cadmium, zinc, copper, arsenic, selenium and mercury in seabirds from the Barents Sea: levels, inter-specific and geographical differences. Sci Total Environ 2003; 306: 133-158.

Stewart GM, Fowler SW, Teyssie JL, Cotret O, Cochran JK, Fisher NS. Contrasting transfer of polonium-210 and lead-210 across three trophic levels in marine plankton. Mar Ecol Prog Ser 2005; 290: 27-33.

Wang WX. Interactions of trace metals and different marine food chains. Mar Ecol Prog Ser 2002; 243: 295-309.

Wang XL, Zauke G-P. Size-dependent bioaccumulation of metals in the amphipod Gammarus zaddachi (Sexton 1912) from the River Hunte (Germany) and its relationship to the permeable body surface area. Hydrobiologia 2004; 515: 11-28.

White SL, Rainbow PS. Heavy metal concentrations and size effects in the mesopelagic decapod crustacean Systellaspis debilis. Mar Ecol Prog Ser 1987; 37: 147-151.

Wilkinson L, editor. SYSTAT 8.0 Statistics. SPSS Inc., Chicago, IL, USA, 1998, pp. 1086 pp.

Zauke G-P, Clason B, Savinov VM, Savinova T. Heavy metals of inshore Benthic invertebrates from the Barents Sea. Sci Total Environ 2003; 306: 99-110.

Zauke G-P, Krause M, Weber A. Trace metals in mesozooplankton of the North Sea: Concentrations in different taxa and preliminary results on bioaccumulation in copepod collectives (Calanus finmarchicus / C. helgolandicus). Int Revue Ges Hydrobiol 1996a; 81: 141-160.

Zauke G-P, Petri G. Metal concentrations in Antarctic Crustacea. The problem of background levels. In: Dallinger R, Rainbow PS, editors. Ecotoxicology of metals in invertebrates. Lewis Publishers, Boca Raton, USA, 1993; pp. 73-101.

Zauke G-P, Petri G, Ritterhoff J, Meurs H-G. Theoretical background for the assessment of the quality status of ecosystems: lessons from studies of heavy metals in aquatic invertebrates. Senckenbergiana marit 1996b; 27: 207-214.

Zauke GP, Savinov VM, Ritterhoff J, Savinova T. Heavy metals in fish from the Barents Sea in (summer 1994). Sci Total Environ 1999; 227: 161-173. 


\section{Table 1}

Quality assurance using certified reference materials randomly allocated within the determi-

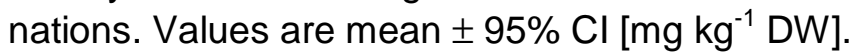

\begin{tabular}{ccccccc}
\hline & \multicolumn{2}{c}{ TORT 2 } & \multicolumn{2}{c}{ CRM 278 } & \multicolumn{2}{c}{ NIST SRM 1566 } \\
& $\begin{array}{c}\text { (Lobster hepatopancreas) } \\
\text { analysed }\end{array}$ & \multicolumn{2}{c}{ certified } & analysed & certified & \multicolumn{2}{c}{ (Onster tissue) } \\
\multicolumn{2}{c}{ analysed } & certified \\
\hline $\mathrm{Pb}$ & $0.34 \pm 0.04$ & $0.35 \pm 0.13$ & $1.80 \pm 0.08$ & $2.00 \pm 0.04$ & $0.40-0.65^{\mathrm{b}}$ & $0.48 \pm 0.04$ \\
$\mathrm{Cu}$ & $106 \pm 5$ & $106 \pm 10$ & $9.90 \pm 0.25$ & $9.45 \pm 0.13$ & $58-67^{\mathrm{b}}$ & $63 \pm 3.5$ \\
$\mathrm{Cd}$ & $25.8 \pm 1.1$ & $26.7 \pm 0.6$ & $0.33 \pm 0.02$ & $0.348 \pm 0.007$ & $3.0-3.6^{\mathrm{b}}$ & $3.5 \pm 0.4$ \\
$\mathrm{Zn}$ & $183 \pm 9^{\mathrm{a}}$ & $180 \pm 5$ & $84 \pm 4^{\mathrm{a}}$ & $83.1 \pm 1.7$ & $870-1100^{\mathrm{b}}$ & $852 \pm 14$ \\
\hline
\end{tabular}

Numbers of independent determinations: ${ }^{\mathrm{a}} 11-13 ;{ }^{\mathrm{b}} 4$ (range); others: $16-19$;

Limits of detection [ $\mathrm{mg} \mathrm{kg}^{-1} \mathrm{DW}$ ] (calculated as 2.6 standard deviations of a "low sample"; Büttner et al., 1980): Pb: 0.4; Cu 2.0; Cd: 0.12; Zn: 5. 
Table 2

Size dependent heterogeneities of trace metal concentrations in Pandalus borealis (small, medium, large) from the Central Bank (2000), Spitsbergen Bellsund Bank (2000) and north of Svalbard (1991): Test of global null hypotheses.

\begin{tabular}{cccccccc}
\hline & Area & LS & $\mathrm{P}$ & Test & Test statistic & $\mathrm{P}$ & $\mathrm{df}$ \\
\hline $\mathrm{Cd}$ & 2 & 1.4 & 0.289 & $\mathrm{~F}$ & 11.4 & 0.001 & 2,13 \\
$\mathrm{Cu}$ & 2 & 3.2 & 0.073 & $\mathrm{~F}$ & 7.9 & 0.006 & 2,13 \\
$\mathrm{Zn}$ & 2 & 2.5 & 0.125 & $\mathrm{~F}$ & 2.0 & 0.183 & 2,13 \\
$\mathrm{Cd}$ & 3 & 5.1 & 0.017 & $\mathrm{WS}$ & 23.2 & 0.000 & 2,9 \\
$\mathrm{Cu}$ & 3 & 8.8 & 0.002 & $\mathrm{WS}$ & 39.7 & 0.000 & 2,9 \\
$\mathrm{Zn}$ & 3 & 13.7 & 0.000 & $\mathrm{WS}$ & 2.0 & 0.195 & 2,9 \\
$\mathrm{Cd}$ & 5 & 1.7 & 0.193 & $\mathrm{~F}$ & 3.1 & 0.053 & 2,49 \\
$\mathrm{Cu}$ & 5 & 18.6 & 0.000 & $\mathrm{WS}$ & 27.7 & 0.000 & 2,15 \\
$\mathrm{Zn}$ & 5 & 1.1 & 0.347 & $\mathrm{~F}$ & 9.3 & 0.000 & 2,48
\end{tabular}

Size of $P$. borealis (rostrum to telson): small $(5.0-7.5 \mathrm{~cm})$, medium $(7.5-10.5 \mathrm{~cm})$, large $(10.5-12.0 \mathrm{~cm})$. LS: Levene statistic (equality of variances); WS: Welch statistic; F: F-value (ANOVA); P: tail probability (corresponding null hypotheses are rejected when $\mathrm{P}<0.05$ ); df: degrees of freedom. Sampling areas see Fig. 1. Pb was not evaluated due to many values below or close to the limit of detection (see Table 1). 
Table 3

Trace metal concentrations in Pandalus borealis from the Norwegian Sea, Barents Sea, Spitsbergen Bellsund Bank and north of Svalbard.

\begin{tabular}{|c|c|c|c|c|c|c|c|c|}
\hline & & & & Mean $\pm 95 \% \mathrm{Cl}$ & & & & Groups \\
\hline & Area & Sampling region & Year & {$\left[\mathrm{mg} \mathrm{kg}^{-1} \mathrm{DW}\right]$} & $\mathrm{N}$ & LIP & Test & 1234 \\
\hline \multirow[t]{6}{*}{$\mathrm{Cd}$} & 1 & North Cape Bank & 2000 & $0.7 \pm 0.1$ & 8 & 0.321 & Z & | \\
\hline & 3 & Bellsund Bank & 2000 & $1.7 \pm 0.3$ & 23 & 0.003 & & $\mid$ \\
\hline & 2 & Central Bank & 2000 & $1.8 \pm 0.2$ & 16 & 0.677 & & $\mid$ \\
\hline & 3 & Bellsund Bank & 1994 & $1.9 \pm 0.4$ & 57 & 0.000 & & | \\
\hline & 2 & Central Bank & 1994 & $2.3 \pm 0.3$ & 27 & 0.170 & & | \\
\hline & 5 & North of Svalbard & 1991 & $4.7 \pm 0.7$ & 53 & 0.027 & & $\mid$ \\
\hline \multirow[t]{6}{*}{$\mathrm{Cu}$} & 2 & Central Bank & 1994 & $15 \pm 4$ & 28 & 0.000 & Z & | \\
\hline & 3 & Bellsund Bank & 1994 & $21 \pm 3$ & 58 & 0.002 & & | \\
\hline & 1 & North Cape Bank & 2000 & $36 \pm 6$ & 8 & 0.082 & & $\mid$ \\
\hline & 5 & North of Svalbard & 1991 & $38 \pm 7$ & 53 & 0.000 & & $\mid$ \\
\hline & 2 & Central Bank & 2000 & $43 \pm 3$ & 16 & 0.659 & & | | \\
\hline & 3 & Bellsund Bank & 2000 & $82 \pm 14$ & 23 & 0.012 & & | \\
\hline \multirow[t]{6}{*}{$\mathrm{Zn}$} & 3 & Bellsund Bank & 1994 & $45 \pm 1$ & 57 & 0.457 & NK & | \\
\hline & 5 & North of Svalbard & 1991 & $53 \pm 3$ & 52 & 0.219 & & $\mid$ \\
\hline & 2 & Central Bank & 1994 & $56 \pm 3$ & 28 & 0.047 & & | \\
\hline & 3 & Bellsund Bank & 2000 & $67 \pm 6$ & 20 & 0.244 & & | \\
\hline & 1 & North Cape Bank & 2000 & $71 \pm 6$ & 8 & 0.643 & & $\mid$ \\
\hline & 2 & Central Bank & 2000 & $81 \pm 4$ & 16 & 0.974 & & \\
\hline
\end{tabular}

LIP: Lilliefors probability that sample data are distributed normally $(\alpha=0.01) ; 95 \% \mathrm{Cl}$ : $95 \%$ confidence intervals. Z: Z statistic; NK: Student-Newman-Keuls Multiple Range Test; Bars (|) indicate homogeneous groups according to the multiple comparison tests; otherwise as in Tables 2 and 4 . $\mathrm{Pb}$ was not evaluated due to many values below or close to the limit of detection (see Table 1). 
Table 4

Interspecific heterogeneities of trace metal concentrations in zooplankton and decapods from the Norwegian Sea, Barents Sea, Spitsbergen Area and Bear Island (2000): StudentNewman-Keuls Multiple Range Test.

\begin{tabular}{|c|c|c|c|c|c|c|c|c|c|c|}
\hline & \multirow[b]{2}{*}{ Collective } & \multirow[b]{2}{*}{ Taxon } & \multicolumn{3}{|l|}{ Mean $\pm 95 \% \mathrm{Cl}$} & \multicolumn{5}{|c|}{ Groups } \\
\hline & & & {$\left[\mathrm{mg} \mathrm{kg}^{-1} \mathrm{DW}\right]$} & $\mathrm{N}$ & LIP & 1 & 2 & 3 & & 5 \\
\hline \multirow[t]{9}{*}{$\mathrm{Cd}$} & Meganyctiphanes norvegica & Eup & $0.2 \pm 0.1$ & 5 & 0.288 & | & & & & \\
\hline & Eukronia hamata & Cha & $0.8 \pm 0.2$ & 8 & 0.867 & & & & & \\
\hline & Pandalus borealis & $\mathrm{Dec}$ & $1.6 \pm 0.2$ & 47 & 0.000 & 1 & & & & \\
\hline & Metridia longa & Cop & $2.4 \pm 0.6$ & 10 & 0.265 & | & & & & \\
\hline & Euchaeta norvegica & Cop & $1.2-4.0^{*}$ & 3 & - & & & & & \\
\hline & Calanus hyperboreus & Cop & $4.2 \pm 1.0$ & 11 & 0.873 & & $\mid$ & & & \\
\hline & Sabinea sarsi & Dec & $4.3 \pm 1.1$ & 20 & 0.005 & & $\mid$ & & & \\
\hline & Calanus finmarchicus & Cop & $6.3 \pm 1.1$ & 12 & 0.096 & & & & & \\
\hline & Themisto abyssorum & Amp & $10.5 \pm 4.0$ & 7 & 0.257 & & & & $\mid$ & \\
\hline \multirow[t]{9}{*}{$\mathrm{Cu}$} & Eukronia hamata & Cha & $4 \pm 1$ & 8 & 0.192 & 1 & & & & \\
\hline & Calanus hyperboreus & Cop & $6 \pm 1$ & 11 & 0.837 & $\mid$ & & & & \\
\hline & Calanus finmarchicus & Cop & $7 \pm 1$ & 13 & 0.597 & 1 & & & & \\
\hline & Metridia longa & Cop & $7 \pm 1$ & 10 & 0.143 & $\mid$ & & & & \\
\hline & Euchaeta norvegica & Cop & $9 \pm 4$ & 4 & 0.913 & $\mid$ & & & & \\
\hline & Themisto abyssorum & Amp & $9 \pm 3$ & 7 & 0.724 & 1 & & & & \\
\hline & Meganyctiphanes norvegica & Eup & $47 \pm 11$ & 5 & 1.000 & & $\mid$ & & & \\
\hline & Pandalus borealis & Dec & $61 \pm 9$ & 47 & 0.000 & & $\mid$ & & & \\
\hline & Sabinea sarsi & Dec & $68 \pm 10$ & 17 & 0.587 & & | & & & \\
\hline \multirow[t]{9}{*}{$\mathrm{Zn}$} & Sabinea sarsi & $\mathrm{Dec}$ & $59 \pm 5$ & 20 & 0.341 & | & & & & \\
\hline & Meganyctiphanes norvegica & Eup & $73 \pm 11$ & 5 & 0.886 & & $\mid$ & & & \\
\hline & Pandalus borealis & Dec & $79 \pm 8$ & 47 & 0.000 & 1 & $\mid$ & & & \\
\hline & Calanus hyperboreus & Cop & $108 \pm 22$ & 12 & 0.006 & & $\mid$ & & & \\
\hline & Themisto abyssorum & Amp & $110 \pm 16$ & 8 & 0.295 & & $\mid$ & & & \\
\hline & Eukronia hamata & Cha & $124 \pm 20$ & 8 & 0.390 & & $\mid$ & & & \\
\hline & Calanus finmarchicus & Cop & $154 \pm 32$ & 14 & 0.510 & & & 1 & & \\
\hline & Euchaeta norvegica & Cop & $251 \pm 61$ & 4 & 1.000 & & & & | & \\
\hline & Metridia longa & Cop & $509 \pm 53$ & 9 & 1.000 & & & & & | \\
\hline
\end{tabular}

Explanations see Tables 2 and 3; Taxon: Eup = Euphausiacea, Dec = Decapoda, Cop = Copepoda, Amp $=$ Amphipoda, Cha $=$ Chaetognatha; ${ }^{*}$ range (not included in the statistical evaluation); $\mathrm{Pb}$ was not evaluated due to many values below or close to the limit of detection (see Table 1). 
Table 5

Mean trace metal concentrations in decapods, euphausiids, amphipods and chaetognaths from different regions of the world $\left[\mathrm{mg} \mathrm{kg}^{-1} \mathrm{DW}\right]$.

\begin{tabular}{|c|c|c|c|c|c|c|c|}
\hline Species & Taxon & Region & $\mathrm{Cd}$ & $\mathrm{Cu}$ & $\mathrm{Pb}$ & $\mathrm{Zn}$ & Ref \\
\hline Systellaspis debilis & Dec & Atlantic, African Coast & 22 & 55 & - & 70 & 1 \\
\hline Systellaspis debilis & Dec & Atlantic, Azores Islands & 13 & - & - & 50 & 2 \\
\hline Systellaspis debilis & Dec & N.E. Atlantic Ocean & 12 & 67 & - & 53 & 3 \\
\hline Systellaspis debilis & Dec & N.E. Atlantic Ocean & 11 & 56 & - & 41 & 4 \\
\hline Systellaspis debilis & Dec & Iberian Deep Sea Plain & 16 & 49 & 0.6 & 62 & 5 \\
\hline Acanthephyra exima & Dec & Atlantic, Azores Islands & 3.0 & - & - & - & 2 \\
\hline Acanthephyra purpurea & Dec & N.E. Atlantic Ocean & 3.0 & 36 & - & 46 & 4 \\
\hline Acanthephyra spec. & Dec & Iberian Deep Sea Plain & 6.1 & 56 & 0.6 & 52 & 5 \\
\hline Bentheogennema intermedia & Dec & Iberian Deep Sea Plain & 11 & 36 & 0.4 & 74 & 5 \\
\hline Benthesicymus iridescens & Dec & Iberian Deep Sea Plain & 15 & 55 & 0.4 & 79 & 5 \\
\hline Sergia spec. & Dec & Iberian Deep Sea Plain & 1.9 & 17 & 0.5 & 67 & 5 \\
\hline Hymenodora glacialis & $\mathrm{Dec}$ & Greenland Sea & 6.7 & 16 & $<0.3$ & 37 & 6 \\
\hline Hymenodora glacialis & Dec & Fram Strait & 9.2 & 12 & $<0.3$ & 52 & 6 \\
\hline Chorismus antarcticus & Dec & Weddell Sea & 13 & 93 & 1.6 & 44 & 7 \\
\hline Notocrangon antarcticus & Dec & Weddell Sea & 13 & 67 & 0.8 & 46 & 7 \\
\hline euphausiids & Eup & Iberian Deep Sea Plain & 0.8 & 25 & 0.3 & 72 & 5 \\
\hline euphausiids & Eup & Central North Sea & 0.2 & 28 & 0.7 & 70 & 8 \\
\hline Euphausia superba & Eup & Weddell Sea & 3.5 & 66 & 0.3 & 33 & 7 \\
\hline Thysanoessa inermis & Eup & Greenland Sea & $<0.1$ & 39 & $<0.3$ & 78 & 6 \\
\hline Meganyctiphanes norvegica & Eup & N. North Sea/Atlantic & 0.5 & 26 & 1.0 & 45 & 8 \\
\hline Meganyctiphanes norvegica & Eup & Greenland Sea & 0.4 & 35 & $<0.3$ & 42 & 6 \\
\hline Meganyctiphanes norvegica & Eup & Mediterranean & 0.1 & - & 0.5 & - & 10 \\
\hline Hyperia spec & Amp & Northern North Sea & 51 & 26 & 1.8 & 72 & 8 \\
\hline Themisto abyssorum & Amp & Greenland Sea & 28 & 24 & 1.0 & 92 & 6 \\
\hline Themisto abyssorum & Amp & Fram Strait & 28 & 22 & 1.2 & 86 & 6 \\
\hline Themisto libellula & Amp & Greenland Sea & 34 & 26 & 0.4 & 61 & 6 \\
\hline Themisto libellula & Amp & Fram Strait & 24 & 23 & 0.5 & 61 & 6 \\
\hline Themisto compressa & Amp & NE Atlantic & 70 & - & - & - & 9 \\
\hline Eukronia hamata & Cha & Greenland Sea & 1.1 & 3 & $<0.3$ & 69 & 6 \\
\hline
\end{tabular}

taxa: Dec = Decapoda $;$ Eup = Euphausiacea $;$ Amp = Amphipoda $;$ Cha $=$ Chaetognatha references: 1: Ridout et al., 1985; 2: Leatherland et al., 1973; 3: White and Rainbow, 1987; 4: Ridout et al., 1989; 5: Prowe et al., in press; 6: Ritterhoff and Zauke, 1997d; 7: Petri and Zauke, 1993; 8: Zauke et al., 1996a; 9: Rainbow and White, 1989; 10: Fossi et al., 2002; 11: Kahle and Zauke, 2003; 12: Pohl, 1992. 
Table 6

Mean trace metal concentrations in copepods from different regions of the world $\left[\mathrm{mg} \mathrm{kg}^{-1} \mathrm{DW}\right]$.

\begin{tabular}{|c|c|c|c|c|c|c|}
\hline Species & Region & $\mathrm{Cd}$ & $\mathrm{Cu}$ & $\mathrm{Pb}$ & $\mathrm{Zn}$ & Ref \\
\hline Calanus finmarchicus & Greenland Sea & 0.3 & 4 & $<0.3$ & 86 & 6 \\
\hline Calanus finmarchicus & Fram Strait & 0.3 & 5 & $<0.3$ & 93 & 6 \\
\hline Calanus finmarchicus & Greenland Sea & 7.7 & 8 & 1.6 & 164 & 12 \\
\hline Calanus finmarchicus & Fram Strait & 6.8 & 5 & 0.7 & 192 & 12 \\
\hline Calanus finmar/helgol.* & German Bight & 0.7 & 4 & 1.0 & 110 & 8 \\
\hline Calanus finmar/helgol. * & Southern North Sea & 1.8 & 7 & 1.0 & 129 & 8 \\
\hline Calanus finmar/helgol.* & Central North Sea & 3.2 & 7 & 1.0 & 123 & 8 \\
\hline Calanus finmar/helgol.* & Northern North Sea & 5.0 & 8 & 1.0 & 98 & 8 \\
\hline Calanus finmar/helgol. * & N. North Sea/Atlantic & 10.9 & 7 & 1.0 & 70 & 8 \\
\hline Calanus hyperboreus & Greenland Sea & 0.7 & 4 & $<0.3$ & 88 & 6 \\
\hline Calanus hyperboreus & Fram Strait & 0.8 & 6 & 0.3 & 104 & 6 \\
\hline Calanus hyperboreus & Greenland Sea & 3.0 & 4 & 0.5 & 85 & 12 \\
\hline Calanus hyperboreus & Fram Strait & - & 5 & 0.6 & 81 & 12 \\
\hline Rhincalanus gigas & Weddell Sea & 3.7 & 11 & 0.2 & 432 & 11 \\
\hline Calanus propinquus & Weddell Sea & 5.6 & 26 & 0.5 & 191 & 11 \\
\hline Calanoides acutus & Weddell Sea & 4.6 & 10 & 0.3 & 183 & 11 \\
\hline Euchaeta norvegica & Greenland Sea & 0.1 & 5 & $<0.3$ & 172 & 6 \\
\hline Euchaetidae & Iberian Deep Sea Plain & 3.8 & 10 & 0.2 & 160 & 5 \\
\hline Metridia longa & Greenland Sea & 0.6 & 6 & 0.5 & 389 & 6 \\
\hline Metridia longa & Fram Strait & 0.7 & 8 & 0.6 & 351 & 6 \\
\hline Metridia curticauda & Weddell Sea & 9.6 & 21 & 0.5 & 278 & 11 \\
\hline Metridia gerlachei & Weddell Sea & 10.2 & 26 & 0.7 & 518 & 11 \\
\hline Centropages spec & Central North Sea & 2.5 & 17 & 2.5 & 391 & 8 \\
\hline Acartia spec & Central North Sea & 1.7 & 15 & 2.0 & 491 & 8 \\
\hline Temora spec & Central North Sea & 1.7 & 34 & 2.7 & 524 & 8 \\
\hline
\end{tabular}

* mixed collectives of $C$. finmarchicus and $C$. helgolandicus; references: see Table 5. 

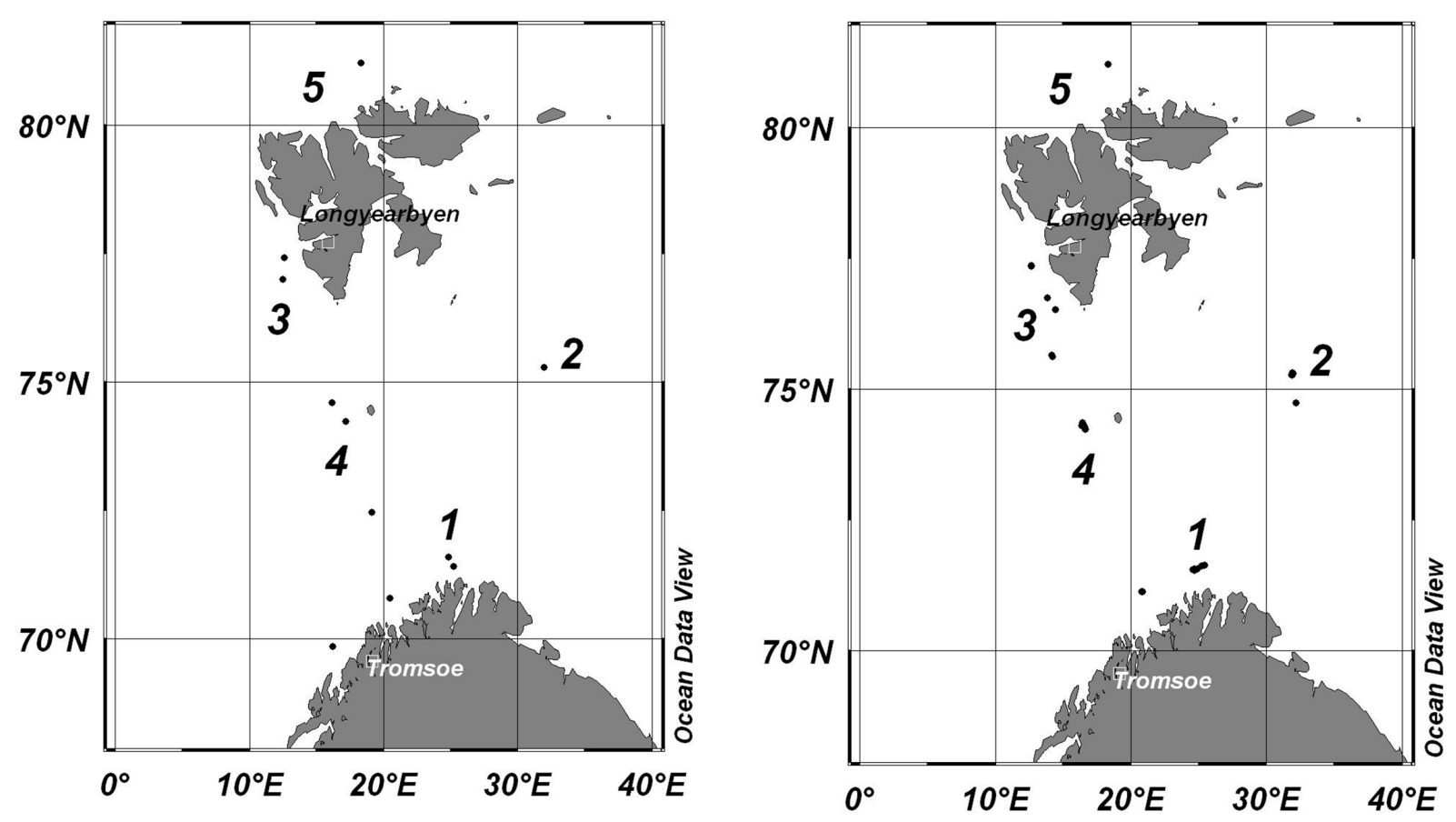

Figure 1: Areas of investigation and sampling locations in the Norwegian Sea and the Barents Sea for the 'Helgoländer Planktonnetz' (left) and the GOV (Chalut à Grande Ouverture Verticale) (right) with (1) North Cape Bank; (2) Central Bank; (3) Spitsbergen Bellsund Bank, Hornsund Bank and South Cape Bank, (4) Bear Island and (5) north of Svalbard (see section 2.1 for further details). 